University of Nebraska - Lincoln

DigitalCommons@University of Nebraska - Lincoln

Faculty Papers and Publications in Animal

Science

Animal Science Department

2003

\title{
Corn Processing Method in Finishing Diets Containing Wet Corn Gluten Feed
}

T. L. Scott

Alltech Biotechnology Inc., 3031 Catnip Hill Pike, Nicholasville, KY

C. T. Milton

University of Nebraska-Lincoln

Galen Erickson

University of Nebraska-Lincoln, gerickson4@unl.edu

Terry Klopfenstein

University of Nebraska-Lincoln, tklopfenstein1@unl.edu

Rick A. Stock

University of Nebraska-Lincoln, rstock3@Unl.edu

Follow this and additional works at: https://digitalcommons.unl.edu/animalscifacpub

Part of the Animal Sciences Commons

Scott, T. L.; Milton, C. T.; Erickson, Galen; Klopfenstein, Terry; and Stock, Rick A., "Corn Processing Method in Finishing Diets Containing Wet Corn Gluten Feed" (2003). Faculty Papers and Publications in Animal Science. 458.

https://digitalcommons.unl.edu/animalscifacpub/458

This Article is brought to you for free and open access by the Animal Science Department at DigitalCommons@University of Nebraska - Lincoln. It has been accepted for inclusion in Faculty Papers and Publications in Animal Science by an authorized administrator of DigitalCommons@University of Nebraska - Lincoln. 


\title{
Corn processing method in finishing diets containing wet corn gluten feed $^{1}$
}

\author{
T. L. Scott ${ }^{2}$, C. T. Milton*, G. E. Erickson*, T. J. Klopfenstein*3 ${ }^{* 3}$ and R. A. Stock $\dagger$ \\ *University of Nebraska, Lincoln 68583-0908 and †Cargill Corn Milling, Blair, NE 68008-0530
}

\begin{abstract}
Two trials were conducted to determine the effect of corn processing method on performance and carcass traits in steers fed finishing diets containing wet corn gluten feed (WCGF). In Trial 1, 480 steer calves (303 kg initial BW) were fed eight finishing diets: 1) dry-rolled corn (DRC) without; and 2) with $32 \%$ (DM basis) WCGF; 3) steam-flaked corn (SFC) without; and 4) with WCGF; 5) a combination of DRC and SFC without WCGF; 6) finely-ground corn (FGC) with WCGF; 7) high-moisture corn (HMC) with WCGF; and 8 ) whole corn (WC) with WCGF. Feeding WC + WCGF increased $(P<0.10)$ DMI and decreased gain:feed compared with all other treatments. Feeding DRC + WCGF increased $(P<0.10)$ DMI and decreased $(P<0.10)$ gain:feed compared with treatments other than WC + WCGF. Steers on treatments that included WCGF gained similarly, regardless of corn processing method, and at a rate $6 \%$ faster $(P<0.10)$ than steers fed diets that did not include WCGF. Gain:feed did not differ among steers fed SFC, SFC + WCGF, SFC + DRC, and $\mathrm{HMC}+\mathrm{WCGF}$. Steers fed SFC or SFC + WCGF were more efficient $(P<0.10)$ than steers fed DRC or FGC + WCGF. In Trial 2, 288 steer calves (382 kg initial
\end{abstract}

BW) were fed six finishing diets: 1) DRC without; and 2) with 22\% (DM basis) WCGF; 3) SFC without; and 4) with WCGF; 5) finely rolled corn (FRC) with WCGF; and 6) HMC corn with WCGF. Steers fed DRC + WCGF or FRC + WCGF consumed more DM $(P<0.10)$ than steers fed DRC, SFC, or SFC + WCGF. Feed intake did not differ between steers fed SFC + WCGF and HMC + WCGF. All treatment groups receiving WCGF consumed more DM $(P<0.10)$ feed than steers fed DRC or SFC without WCGF. Steers fed SFC + WCGF gained $8 \%$ faster $(P<0.10)$, and steers fed DRC $9.5 \%$ slower $(P<0.10)$ than steers receiving all other treatments. Daily gains did not differ among other treatment groups. Steers fed SFC or SFC + WCGF gained 10\% more $(P<0.10)$ efficiently than all other treatment groups. Feed efficiency did not differ among steers fed DRC, DRC + WCGF, FRC + WCGF, and HMC + WCGF . Estimates for the $\mathrm{NE}_{\mathrm{g}}$ of WCGF calculated from animal performance indicated that WCGF contained approximately $25.3 \%$ more energy when fed with SFC than when fed with DRC. In general, more intensively processing corn improved gain:feed in finishing diets containing WCGF.

Key Words: Cattle Feeding, Feedlots, Maize Byproducts, Maize Gluten, Maize Starch

(c)2003 American Society of Animal Science. All rights reserved.

J. Anim. Sci. 2003. 81:3182-3190

\section{Introduction}

A substantial portion of the corn produced in the United States is marketed through livestock. In cattle, the price per unit of energy relative to forages makes feeding grain attractive. Corn grain is approximately $72 \%$ starch (Huntington, 1997). Thus, the starch content of corn is primarily responsible for the ability of corn to promote high levels of production. With starch

\footnotetext{
${ }^{1}$ Published with approval of the director as paper no. 13187, journal series, Nebraska Agric. Res. Div.

${ }^{2}$ Present address: Alltech Biotechnology Inc., 3031 Catnip Hill Pike, Nicholasville, KY.

${ }^{3}$ Correspondence: C220 Animal Science (phone: 402-472-6443; fax: 402-472-6362; E-mail: tklopfenstein1@unl.edu).

Received January 11, 2002.

Accepted July 30, 2003.
}

being the major energy component of corn, optimal starch utilization is critical to improving the efficiency of conversion of corn to animal product. Many methods of processing corn have been employed in an attempt to improve its utilization by livestock. Processing methods exist that make use of various factors and/or combinations of factors, including heat, moisture, time, and mechanical action (Huntington, 1997). The underlying goal is to increase the amount of energy (starch) available to the animal, thereby, increasing gain efficiency.

Inclusion of wet corn gluten feed (WCGF) in place of corn grain in finishing diets replaces dietary starch with highly digestible fiber. The resultant effect can be increased feed intake, daily gain, and feed efficiency (Stock et al., 2000) as well as decreased incidence and severity of acidosis in finishing cattle (Krehbiel et al., 1995). Limited information is available about the effects that different grain processing methods may have in diets containing WCGF. 
Table 1. Composition of finishing diets in Trial 1 (DM basis)

\begin{tabular}{|c|c|c|c|c|c|c|c|c|}
\hline \multirow[b]{2}{*}{ Item } & \multicolumn{8}{|c|}{ Treatment $^{\mathrm{a}}$} \\
\hline & $\mathrm{DRC}$ & $\begin{array}{l}\text { DRC } \\
\text { WCGF }\end{array}$ & $\mathrm{SFC}$ & $\begin{array}{l}\text { SFC } \\
\text { WCGF }\end{array}$ & $\begin{array}{l}\text { SFC } \\
\text { DRC }\end{array}$ & $\begin{array}{l}\text { FGC } \\
\text { WCGF }\end{array}$ & $\begin{array}{l}\text { HMC } \\
\text { WCGF }\end{array}$ & $\begin{array}{l}\text { WC } \\
\text { WCGF }\end{array}$ \\
\hline \multicolumn{9}{|l|}{ Ingredient, \% } \\
\hline DRC & 81.55 & 52.50 & - & - & 30.99 & - & - & - \\
\hline FGC & - & - & - & - & - & 52.50 & - & - \\
\hline HMC & - & - & - & - & - & - & 52.50 & - \\
\hline SFC & - & - & 81.55 & 52.50 & 50.56 & - & - & - \\
\hline $\mathrm{WC}$ & - & - & - & - & - & - & - & 52.50 \\
\hline WCGF & - & 32.00 & - & 32.00 & - & 32.00 & 32.00 & 32.00 \\
\hline Alfalfa hay & 7.50 & 7.50 & 7.50 & 7.50 & 7.50 & 7.50 & 7.50 & 7.50 \\
\hline Molasses & 3.00 & 3.00 & 3.00 & 3.00 & 3.00 & 3.00 & 3.00 & 3.00 \\
\hline Dry supplement & 7.95 & 5.00 & 7.95 & 5.00 & 7.95 & 5.00 & 5.00 & 5.00 \\
\hline \multicolumn{9}{|c|}{ Nutrient composition, $\%$} \\
\hline $\mathrm{CP}$ & 14.6 & 14.3 & 14.6 & 14.3 & 14.6 & 14.3 & 14.7 & 14.3 \\
\hline $\mathrm{Ca}$ & 0.73 & 0.75 & 0.73 & 0.75 & 0.73 & 0.75 & 0.77 & 0.75 \\
\hline $\mathrm{P}$ & 0.32 & 0.50 & 0.32 & 0.50 & 0.32 & 0.50 & 0.48 & 0.50 \\
\hline $\mathrm{K}$ & 0.75 & 0.99 & 0.75 & 0.99 & 0.75 & 0.99 & 1.09 & 0.99 \\
\hline $\mathrm{S}$ & 0.18 & 0.27 & 0.18 & 0.27 & 0.18 & 0.27 & 0.28 & 0.27 \\
\hline
\end{tabular}

${ }^{a} \mathrm{DRC}=$ dry-rolled corn; FGC = finely ground corn; HMC = high-moisture corn; SFC = steam-flaked corn; $\mathrm{WC}=$ whole corn; $\mathrm{WCGF}=$ wet corn gluten feed.

Our hypothesis is that diets containing WCGF may be enhanced when corn is processed more intensely due to lower incidence and severity of acidosis in diets containing WCGF. The objective of this research was to evaluate different corn processing methods with or without wet corn gluten feed on performance and carcass characteristics of finishing beef cattle.

\section{Materials and Methods}

\section{Trial 1}

Four hundred eighty English $\times$ Continental steer calves (303 $\pm 23 \mathrm{~kg}$ initial BW) of mixed origin and purchased through sale barns were stratified by weight and assigned randomly to 1 of 32 pens ( 15 steers/pen). To minimize pen-to-pen variation, steers were divided into 15 weight strata with 32 steers each. Each pen (four pens/treatment) was assigned randomly to one of eight dietary treatments. Treatments were finishing diets (Table 1) that contained the following: 1) dryrolled corn (DRC) without; or 2) with wet corn gluten feed (WCGF; Sweet Bran 60, Cargill Corn Milling, Blair, NE); 3) steam-flaked corn (SFC) without; or 4) with WCGF; 5) a combination of DRC and SFC without WCGF; 6) finely-ground corn (FGC) with WCGF; 7) high-moisture corn (HMC) with WCGF; and 8) whole corn (WC) with WCGF.

Steam-flaked corn was processed to a flake density of $0.37 \mathrm{~kg} / \mathrm{L}$ ( 29 pounds/bushel) at a commercial feedlot (Hi-Gain Feedlot, Inc., Cozad, NE) and delivered to the research feedlot on a weekly basis. Dry-rolled corn was coarsely rolled with approximately 95\% of kernels cracked and kernels split into thirds. In the treatment containing a combination of DRC and SFC without WCGF, DRC replaced WCGF in an equal proportion to the substitution of SFC with WCGF in the SFC with WCGF treatment. Finely ground corn was processed through a hammer mill (6.4-mm screen) at the University of Nebraska research feed mill (Mead, NE). Highmoisture corn was harvested at approximately 29\% moisture, processed through a roller mill (coarse roll with kernels cracked), and stored in a covered concrete bunker. In finishing diets containing WCGF, the WCGF was included at $32 \%$ of the dietary DM and replaced corn grain and dry supplement. The supplement (Table 2 ) in diets not containing WCGF included 5\% soybean meal (DM basis) as a source of ruminally degradable natural protein to ensure sufficient metabolizable protein. Because of bunk management problems related to the accumulation of fines, the molasses level in the FGC diet was increased to 6\% (DM basis) on d 87 with the additional molasses replacing FGC.

Steers were weighed initially on two consecutive days after being limit-fed a 50\% alfalfa hay:50\% wet corn gluten feed diet at 2\% (DM basis) of BW for $5 \mathrm{~d}$ to minimize gut fill differences. Steers were implanted with Synovex-S (20 mg of estradiol benzoate and 200 $\mathrm{mg}$ of progesterone; Ft. Dodge Animal Health, Overland Park, KS) on d 1 and reimplanted with Synovex-Plus (28 mg of estradiol benzoate and $200 \mathrm{mg}$ of trenbolone acetate; Ft. Dodge Animal Health) on d 87. Hot carcass weights were collected at the time of slaughter, whereas other carcass traits were collected following a 24-h chill. Marbling scores and yield grades were determined by a USDA grader, whereas 12th-rib fat thickness and longissimus muscle area were recorded by university personnel. Final weights were calculated using hot carcass weights adjusted to a common dressing percent $(63 \%)$.

Weekly samples of DRC, SFC, FGC, HMC, WC, WCGF, and alfalfa hay were composited, analyzed for 
Table 2. Composition of supplements used in Trials 1 and 2 (DM basis)

\begin{tabular}{|c|c|c|c|c|}
\hline \multirow[b]{2}{*}{ Ingredient } & \multicolumn{2}{|c|}{ Trial 1} & \multicolumn{2}{|c|}{ Trial 2} \\
\hline & Corn $^{a}$ & $\mathrm{WCGF}^{\mathrm{b}}$ & Corn $^{a}$ & $\mathrm{WCGF}^{\mathrm{c}}$ \\
\hline Soybean meal & 62.90 & - & 49.99 & 21.20 \\
\hline Fine ground corn & - & 58.64 & 2.87 & 33.18 \\
\hline Limestone & 17.19 & 29.06 & 19.39 & 27.92 \\
\hline Urea & 11.27 & - & 16.64 & 5.40 \\
\hline Salt & 3.77 & 6.00 & 4.29 & 6.00 \\
\hline Ammonium chloride & 3.14 & 5.00 & 3.57 & 5.00 \\
\hline Dicalcium phosphate & 0.92 & - & 1.63 & - \\
\hline Potassium chloride & - & - & - & 0.69 \\
\hline Trace mineral premix ${ }^{\mathrm{d}}$ & 0.25 & 0.40 & 0.29 & 0.40 \\
\hline Rumensin premix ${ }^{\mathrm{e}}$ & 0.21 & 0.34 & 0.24 & 0.34 \\
\hline Vitamin premix ${ }^{f}$ & 0.19 & 0.30 & 0.21 & 0.30 \\
\hline Tylan premix ${ }^{\mathrm{g}}$ & 0.16 & 0.26 & 0.19 & 0.26 \\
\hline
\end{tabular}

${ }^{\mathrm{a} C o r n}=$ diets containing only corn grain.

${ }^{\mathrm{b}} \mathrm{WCGF}=$ diets containing corn grain and $32 \%$ wet corn gluten feed.

${ }^{\mathrm{c}} \mathrm{WCGF}=$ diets containing corn grain and $22 \%$ wet corn gluten feed.

${ }^{\mathrm{d}}$ Contained $10 \% \mathrm{Mg}, 6 \% \mathrm{Zn}, 4.5 \% \mathrm{Fe}, 2 \% \mathrm{Mn}, 0.5 \% \mathrm{Cu}, 0.3 \% \mathrm{I}$, and $0.05 \%$ Co.

${ }^{\mathrm{e}}$ Contained $176 \mathrm{~g}$ of monensin per kg of premix (Elanco Animal Health, Greenfield, IN).

${ }^{\mathrm{f}}$ Contained 15,000 IU of vitamin A, 3,000 IU of vitamin D, and $3.75 \mathrm{IU}$ of vitamin E/g of premix.

${ }^{\mathrm{g}}$ Contained $88 \mathrm{~g}$ of tylosin/kg of premix (Elanco Animal Health).

DM by drying in a $60^{\circ} \mathrm{C}$ oven for $48 \mathrm{~h}$, ground to pass a 0.85 -mm screen, and analyzed for $\mathrm{N}$ using a combustion N analyzer (Perkin-Elmer, model PE 2410 Series II, Norwalk, CT). Crude protein values for other dietary ingredients were based on NRC (1996) tabular values. Values for Ca, P, K, and S were based on NRC (1996) tabular values. Net energy for gain of each diet was calculated from performance using the iterative procedure outlined by Zinn (1987). In DRC and SFC diets without WCGF, $\mathrm{NE}_{\mathrm{g} v a l u e s}$ were calculated from performance by difference for DRC and SFC, with tabular $\mathrm{NE}_{\mathrm{g}}$ values (NRC, 1996) assumed for ingredients other than DRC and SFC. The following formula was used: $\mathrm{NE}_{\mathrm{g}}[\mathrm{DRC}$ or $\mathrm{SFC}]=\left(\mathrm{NE}_{\mathrm{g}}\right.$ [Diet] $-\mathrm{NE}_{\mathrm{g}}$ [dietary ingredients other than DRC or SFC])/\% DRC or SFC in the diet. The calculated $\mathrm{NE}_{\mathrm{g}}$ values for $\mathrm{DRC}$ and $\mathrm{SFC}$ then were used to allow calculation of the $\mathrm{NE}_{\mathrm{g}}$ value for WCGF when fed in combination with either DRC or SFC. The following formula was used: $\mathrm{NE}_{\mathrm{g}}$ [WCGF] $=\left(\mathrm{NE}_{\mathrm{g}}\right.$ [Diet] $-\mathrm{NE}_{\mathrm{g}}$ [dietary ingredients other than WCGF])/\% WCGF in the diet.

On d 170, two fecal grab samples were taken from fresh feces available on the pen surface from two pens receiving each treatment for fecal starch analysis. Fecal samples were analyzed for DM by drying in a $60^{\circ} \mathrm{C}$ oven for $48 \mathrm{~h}$ and analyzed in triplicate for starch content using enzymatic hydrolysis and glucose oxidase (Murphy et al., 1994). Laboratory DM of fecal samples was determined by drying in a $100^{\circ} \mathrm{C}$ oven for $12 \mathrm{~h}$.

\section{Trial 2}

Two hundred eighty-eight English $\times$ Continental yearling steers (382 $\pm 26 \mathrm{~kg}$ initial BW) of mixed origin and purchased through sale barns were stratified by weight and assigned randomly to 1 of 24 pens ( 12 steers/ pen) similar to Trial 1. Each pen (four pens/treatment) was assigned randomly to one of six dietary treatments. Treatments were finishing diets (Table 3) that contained the following: 1) DRC without; or 2) with WCGF; 3) SFC without; or 4) with WCGF; 5) finely rolled corn with WCGF; and 6) high-moisture corn with WCGF.

Processing procedures and sources of both SFC and HMC were the same as in Trial 1 . Finely rolled corn was processed through a roller mill, with rolls set as close as possible. The WCGF used in Trial 2 was from the same source as that used in Trial 1 and was included at $22 \%$ of the dietary DM, replacing corn grain and dry supplement. The level of WCGF was reduced in Trial 2 because it was believed that the lower level more closely approximated the level being utilized in the commercial cattle feeding industry. Supplemental protein (Table 2) in all finishing diets was supplied with urea and soybean meal in a 60:40 ratio (CP basis). Steers were implanted with Synovex-Plus on d 28. Weighing and slaughter procedures and calculations of final weights, $\mathrm{CP}, \mathrm{Ca}, \mathrm{P}, \mathrm{K}$, and $\mathrm{S}$ concentrations and $\mathrm{NE}_{\mathrm{g}}$ of each diet were the same as in Trial 1.

\section{Particle Size Analysis}

Samples of corn grain from each of the processing methods used in Trials 1 and 2 were taken weekly, dried in a $60^{\circ} \mathrm{C}$ oven and composited for particle size analysis (ASAE, 1969). Samples were measured in triplicate to determine corn particle size distribution, geometric mean diameter, and geometric standard deviation for each processing method.

\section{Statistical Analyses and Animal Care}

Animal care and procedures used in Trial 1 and Trial 2 were approved by the University of Nebraska Insti- 
Wet corn gluten feed and corn processing method

Table 3. Composition of finishing diets in Trial 2 (DM basis)

\begin{tabular}{|c|c|c|c|c|c|c|}
\hline \multirow[b]{2}{*}{ Item } & \multicolumn{6}{|c|}{ Treatment $^{\mathrm{a}}$} \\
\hline & $\mathrm{DRC}$ & $\begin{array}{l}\text { DRC } \\
\text { WCGF }\end{array}$ & $\mathrm{SFC}^{\mathrm{b}}$ & $\begin{array}{l}\text { SFC } \\
\text { WCGF }\end{array}$ & $\begin{array}{l}\text { FRC } \\
\text { WCGF }\end{array}$ & $\begin{array}{l}\text { HMC } \\
\text { WCGF }\end{array}$ \\
\hline \multicolumn{7}{|l|}{ Ingredient, \% } \\
\hline DRC & 82.50 & 62.50 & - & - & - & - \\
\hline FRC & - & - & - & - & 62.50 & - \\
\hline HMC & - & - & - & - & - & 62.50 \\
\hline $\mathrm{SFC}$ & - & - & 84.50 & 62.50 & - & - \\
\hline WCGF & - & 22.00 & - & 22.00 & 22.00 & 22.00 \\
\hline Alfalfa hay & 7.50 & 7.50 & 7.50 & 7.50 & 7.50 & 7.50 \\
\hline Molasses & 3.00 & 3.00 & 3.00 & 3.00 & 3.00 & 3.00 \\
\hline Dry supplement & 7.00 & 5.00 & 5.00 & 5.00 & 5.00 & 5.00 \\
\hline \multicolumn{7}{|c|}{ Nutrient composition, \% } \\
\hline $\mathrm{CP}$ & 14.6 & 14.1 & 13.3 & 14.2 & 14.1 & 14.7 \\
\hline $\mathrm{Ca}$ & 0.73 & 0.72 & 0.57 & 0.72 & 0.72 & 0.75 \\
\hline $\mathrm{P}$ & 0.32 & 0.44 & 0.32 & 0.44 & 0.44 & 0.41 \\
\hline $\mathrm{K}$ & 0.71 & 0.90 & 0.70 & 0.90 & 0.90 & 1.03 \\
\hline $\mathrm{S}$ & 0.18 & 0.24 & 0.17 & 0.24 & 0.24 & 0.25 \\
\hline
\end{tabular}

${ }^{\mathrm{a} D R C}=$ dry-rolled corn; FRC = finely rolled corn; HMC = high-moisture corn; SFC = steam-flaked corn; WCGF = wet corn gluten feed.

${ }^{\mathrm{b}} \mathrm{A}$ feed delivery error resulted in only $5 \%$ supplement being fed. The amount should have been $7 \%$; therefore, vitamins, minerals, feed additives, and supplemental protein were underfed by $28.6 \%$.

tute for Animal Care and Use Committee (IACUC \#9804-021).

Trial 1 and Trial 2. Performance, carcass, and fecal starch data from Trial 1 were analyzed as a completely randomized design experiment with the MIXED procedure of SAS (SAS Inst. Inc., Cary, NC). Treatment means were separated using a Bonferroni $t$-test and the LSMEANS statement and PDIFF option of SAS when protected by an $F$-value of $P<0.05$. In both analyses of variance for performance and carcass data, pen was the experimental unit and treatment was included as the model effect. For fecal starch data in Trial 1, sample was the experimental unit and treatment was included as the model effect. Percentage of carcasses grading USDA Choice or higher was analyzed using chi-squared analysis and FREQ procedures of SAS. Individual carcass was used as the experimental unit for USDA quality grade with carcasses assigned quality grade based on marbling score.

Particle Size Analyses. Particle size data were analyzed using the MIXED procedure of SAS for a completely randomized design. Treatment means were separated using the LSMEANS statement and PDIFF option of SAS when protected by an $F$-value of $P<0.05$. Laboratory replicate was the experimental unit and treatment was included as the model effect.

\section{Results}

\section{Particle Size Analysis}

Corn particle size distribution, geometric mean diameter, and geometric standard deviation for each processing method are presented in Table 4 . The geometric mean diameter of $\mathrm{WC}$ was higher $(P<0.001)$ than all other treatments. Likewise, the geometric mean diame- ter of FGC was lower $(P<0.001)$ than all other treatments. The geometric mean diameter of DRC was higher $(P<0.001)$ than SFC, FRC, and HMC, whereas the geometric mean diameter of SFC was similar to FRC and higher $(P<0.09)$ than HMC. The geometric mean diameter of FRC and HMC were similar. The geometric standard deviation for FGC was higher $(P<$ $0.001)$ than all other treatments. The geometric standard deviation for SFC and HMC were intermediate and higher $(P<0.001)$ than FRC, DRC, and WC. The geometric standard deviation for FRC and DRC were similar and higher $(P<0.001)$ than WC.

\section{Trial 1}

Steers fed WC + WCGF consumed $14 \%$ more $(P<$ $0.10)$ feed daily than the average of all other treatments (Table 5). Similarly, steers fed DRC + WCGF consumed $9 \%$ more $(P<0.10)$ feed daily than steers receiving treatments other than WC + WCGF. Steers fed SFC + WCGF, FGC + WCGF, and HMC + WCGF consumed quantities of DM similar to each other but greater $(P$ $<0.10)$ than steers fed DRC, SFC, and SFC + DRC.

Daily gains of steers fed DRC were reduced $(P<0.10)$ $9.3 \%$, on average, compared with all other treatments (Table 5). Daily gains among steers fed DRC + WCGF, $\mathrm{SFC}+\mathrm{WCGF}, \mathrm{FGC}+\mathrm{WCGF}, \mathrm{HMC}+\mathrm{WCGF}$, and WC + WCGF were similar and averaged $1.89 \mathrm{~kg} / \mathrm{d}$. Steers fed SFC or SFC + DRC gained similarly but at a slower $(P<0.10)$ rate than steers fed SFC + WCGF. On average, steers fed WCGF with DRC or SFC gained 8\% faster than steers SFC or DRC alone.

Feed efficiency was $11 \%$ poorer $(P<0.10)$ in steers fed WC + WCGF compared with the average of all other treatments (Table 5). Similarly, feed efficiency was $9 \%$ poorer $(P<0.10)$ in steers fed DRC + WCGF compared 
Table 4. Particle size distribution, geometric mean diameter, and geometric mean diameter standard deviation of processed corn grain fed in Trials 1 and 2

\begin{tabular}{|c|c|c|c|c|c|c|c|}
\hline \multirow[b]{2}{*}{ Item } & \multicolumn{6}{|c|}{ Grain source $^{\mathrm{a}}$} & \multirow[b]{2}{*}{ SEM } \\
\hline & WC & DRC & $\mathrm{SFC}$ & FRC & HMC & FGC & \\
\hline & & 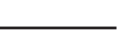 & ticle size d & ribution, ? & & & \\
\hline \multicolumn{8}{|c|}{ Screen size, $\mu \mathrm{m}$} \\
\hline 4,750 & $99.4^{\mathrm{e}}$ & $53.5^{\mathrm{g}}$ & $60.5^{\mathrm{f}}$ & $27.9^{\mathrm{h}}$ & $49.4^{\mathrm{g}}$ & $0.0^{\mathrm{i}}$ & 2.3 \\
\hline 3,350 & $0.5^{\mathrm{i}}$ & $40.7^{\mathrm{f}}$ & $18.3^{\mathrm{h}}$ & $54.1^{\mathrm{e}}$ & $27.2^{\mathrm{g}}$ & $1.3^{\mathrm{i}}$ & 1.2 \\
\hline 1,700 & $0.1^{\mathrm{i}}$ & $5.0^{\mathrm{h}}$ & $13.2^{\mathrm{fg}}$ & $15.9^{\mathrm{e}}$ & $14.4^{\mathrm{ef}}$ & $12.7^{\mathrm{g}}$ & 0.6 \\
\hline 1,410 & $0.0^{\mathrm{h}}$ & $0.3^{\mathrm{h}}$ & $1.5^{\mathrm{f}}$ & $0.9^{\mathrm{g}}$ & $1.4^{\mathrm{f}}$ & $6.3^{\mathrm{e}}$ & 0.2 \\
\hline 1,180 & $0.0^{\mathrm{h}}$ & $0.1^{\mathrm{h}}$ & $1.0^{\mathrm{f}}$ & $0.4^{\mathrm{g}}$ & $1.2^{\mathrm{f}}$ & $8.0^{\mathrm{e}}$ & 0.1 \\
\hline 850 & $0.0^{\mathrm{g}}$ & $0.1^{\mathrm{g}}$ & $1.4^{\mathrm{f}}$ & $0.3^{\mathrm{g}}$ & $1.5^{\mathrm{f}}$ & $15.7^{\mathrm{e}}$ & 0.4 \\
\hline 600 & $0.0^{\mathrm{g}}$ & $0.1^{\mathrm{g}}$ & $1.0^{\mathrm{f}}$ & $0.0^{\mathrm{g}}$ & $1.1^{\mathrm{f}}$ & $14.2^{\mathrm{e}}$ & 0.3 \\
\hline$<600$ & $0.0^{\mathrm{g}}$ & $0.1^{\mathrm{g}}$ & $3.1^{\mathrm{f}}$ & $0.4^{\mathrm{g}}$ & $3.7^{\mathrm{f}}$ & $41.7^{\mathrm{e}}$ & 0.4 \\
\hline GMD, $\mu \mathrm{m}^{\mathrm{c}}$ & $5,511^{\mathrm{e}}$ & $4,619^{\mathrm{f}}$ & $3,991^{\mathrm{g}}$ & $3,977^{\mathrm{g}}$ & $3,760^{\mathrm{h}}$ & $715^{\mathrm{i}}$ & 90 \\
\hline $\mathrm{GSD}^{\mathrm{d}}$ & $1.0^{\mathrm{h}}$ & $1.7^{\mathrm{g}}$ & $2.7^{\mathrm{f}}$ & $1.7^{\mathrm{g}}$ & $2.7^{\mathrm{f}}$ & $5.8^{\mathrm{e}}$ & 0.1 \\
\hline
\end{tabular}

${ }^{\mathrm{a}} \mathrm{WC}=$ whole corn; $\mathrm{DRC}=$ dry-rolled corn; $\mathrm{SFC}=$ steam-flaked corn; FRC $=$ finely-rolled corn; HMC = high-moisture corn; FGC = finely ground corn.

${ }^{b}$ Percentage of sample (DM basis) remaining on screen.

${ }^{\mathrm{c}} \mathrm{GMD}=$ geometric mean diameter.

${ }^{\mathrm{d}} \mathrm{GSD}=$ geometric standard deviation.

e,f,g,h,i Means within a row without a common superscript letter differ $(P<0.10)$.

with the average of treatments other than WC + WCGF. Gain:feed was greater $(P<0.10)$ in steers fed SFC and $\mathrm{SFC}+$ WCGF than in steers fed DRC, DRC + WCGF, and FGC + WCGF. Gain:feed was similar in steers fed $\mathrm{SFC}$, SFC + WCGF, SFC + DRC, and HMC + WCGF and in steers fed DRC, SFC + DRC, FGC + WCGF, and $\mathrm{HMC}+$ WCGF.

Dietary $\mathrm{NE}_{\mathrm{g}}$ was $12 \%$ lower $(P<0.10)$ in steers fed $\mathrm{WC}+\mathrm{WCGF}$ compared with the average of all other treatments (Table 5). Likewise, dietary $\mathrm{NE}_{\mathrm{g}}$ was $9 \%$ lower $(P<0.10)$ in steers fed DRC + WCGF compared with the average of steers receiving treatments other than WC + WCGF. Dietary $\mathrm{NE}_{\mathrm{g}}$ in steers fed SFC was similar to that of steers fed SFC + WCGF and SFC + DRC and greater $(P<0.10)$ than that of steers fed DRC, $\mathrm{FGC}+\mathrm{WCGF}$, and HMC + WCGF. Dietary $\mathrm{NE}_{\mathrm{g}}$ was similar among steers fed SFC + WCGF, SFC + DRC, and HMC + WCGF and among steers fed DRC, SFC + DRC, FGC + WCGF, HMC + WCGF.

Hot carcass weights for steers fed DRC were $13 \mathrm{~kg}$ lighter $(P<0.10)$ compared with the average of all other treatments (Table 5). Averaging $393 \mathrm{~kg}$, steers fed DRC

Table 5. Effects of grain processing method and wet corn gluten feed inclusion in finishing diets on performance, carcass characteristics, and fecal starch (Trial 1)

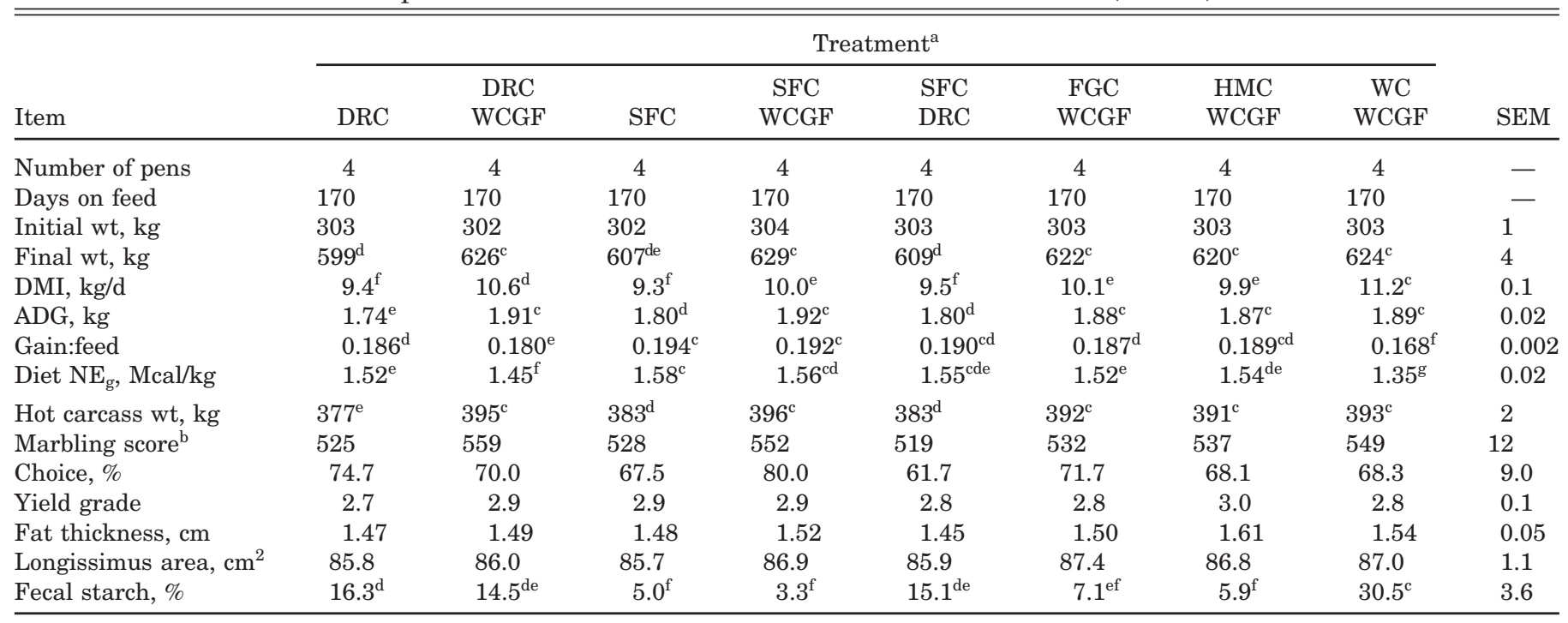

${ }^{\mathrm{a} D R C}=$ dry-rolled corn; FGC = finely ground corn; HMC = high-moisture corn; $\mathrm{SFC}=$ steam-flaked corn; WC = whole corn; WCGF = wet corn gluten feed.

${ }^{\mathrm{b}}$ Marbling score: 500 = small; $600=$ modest.

c,d,e,f,g Means within a row without a common superscript letter differ $(P<0.10)$. 
Table 6. Effects of grain processing method and wet corn gluten feed inclusion in finishing diets on performance and carcass characteristics (Trial 2)

\begin{tabular}{|c|c|c|c|c|c|c|c|}
\hline \multirow[b]{2}{*}{ Item } & \multicolumn{6}{|c|}{ Treatment $^{\mathrm{a}}$} & \multirow[b]{2}{*}{ SEM } \\
\hline & $\mathrm{DRC}$ & $\begin{array}{c}\text { DRC } \\
\text { WCGF }\end{array}$ & $\mathrm{SFC}$ & $\begin{array}{c}\text { SFC } \\
\text { WCGF }\end{array}$ & $\begin{array}{c}\text { FRC } \\
\text { WCGF }\end{array}$ & $\begin{array}{c}\text { HMC } \\
\text { WCGF }\end{array}$ & \\
\hline Number of pens & 4 & 4 & 4 & 4 & 4 & 4 & - \\
\hline Days on feed, d & 117 & 117 & 117 & 117 & 117 & 117 & - \\
\hline Initial wt, kg & 379 & 383 & 383 & 384 & 382 & 385 & 2 \\
\hline Final wt, kg & $573^{\mathrm{e}}$ & $594^{\mathrm{d}}$ & $597^{\mathrm{d}}$ & $608^{\mathrm{c}}$ & $591^{\mathrm{d}}$ & $598^{\mathrm{d}}$ & 4 \\
\hline DMI, kg/d & $10.0^{\mathrm{e}}$ & $11.0^{\mathrm{c}}$ & $10.1^{\mathrm{e}}$ & $10.6^{\mathrm{d}}$ & $11.0^{\mathrm{c}}$ & $10.9^{\mathrm{cd}}$ & 0.1 \\
\hline $\mathrm{ADG}, \mathrm{kg}$ & $1.66^{\mathrm{e}}$ & $1.81^{\mathrm{d}}$ & $1.83^{\mathrm{d}}$ & $1.92^{\mathrm{c}}$ & $1.79^{\mathrm{d}}$ & $1.82^{\mathrm{d}}$ & 0.03 \\
\hline Gain:feed & $0.166^{\mathrm{d}}$ & $0.164^{\mathrm{d}}$ & $0.180^{\mathrm{c}}$ & $0.181^{\mathrm{c}}$ & $0.162^{\mathrm{d}}$ & $0.167^{\mathrm{d}}$ & 0.002 \\
\hline Diet $\mathrm{NE}_{\mathrm{g}}, \mathrm{Mcal} / \mathrm{kg}$ & $1.42^{\mathrm{d}}$ & $1.39^{\mathrm{de}}$ & $1.53^{\mathrm{c}}$ & $1.53^{\mathrm{c}}$ & $1.37^{\mathrm{e}}$ & $1.42^{\mathrm{d}}$ & 0.02 \\
\hline Hot carcass wt, kg & $361^{\mathrm{e}}$ & $375^{\mathrm{d}}$ & $376^{\mathrm{d}}$ & $383^{c}$ & $373^{\mathrm{d}}$ & $377^{\mathrm{cd}}$ & 2 \\
\hline Marbling score ${ }^{b}$ & 488 & 513 & 496 & 516 & 503 & 516 & 9 \\
\hline Choice, \% & 47.5 & 55.8 & 54.9 & 60.4 & 61.4 & 60.4 & 7.3 \\
\hline Yield grade & $2.0^{\mathrm{e}}$ & $2.4^{\mathrm{cd}}$ & $2.3^{\mathrm{d}}$ & $2.6^{\mathrm{c}}$ & $2.3^{\mathrm{d}}$ & $2.4^{\mathrm{cd}}$ & 0.1 \\
\hline Fat thickness, cm & $1.10^{\mathrm{e}}$ & $1.22^{\mathrm{de}}$ & $1.28^{\mathrm{d}}$ & $1.41^{\mathrm{c}}$ & $1.26^{\mathrm{d}}$ & $1.33^{\mathrm{cd}}$ & 0.05 \\
\hline Longissimus area, $\mathrm{cm}^{2}$ & 89.2 & 90.1 & 93.0 & 91.1 & 90.8 & 90.7 & 1.0 \\
\hline
\end{tabular}

${ }^{\mathrm{a} D R C}=$ dry-rolled corn; FRC = finely rolled corn; HMC = high-moisture corn; SFC = steam-flaked corn;

$\mathrm{WCGF}=$ wet corn gluten feed.

${ }^{\mathrm{b}}$ Marbling score: $500=$ small; $600=$ modest.

${ }^{c, d, e}$ Means within a row without a common superscript letter differ $(P<0.10)$.

+ WCGF, SFC + WCGF, FGC + WCGF, HMC + WCGF, and WC + WCGF had hot carcass weights that were similar to each other but heavier than steers fed SFC or SFC + WCGF. No statistical differences were observed among treatments for marbling score, USDA yield grade, 12th-rib fat thickness, or longissimus muscle area. The averages across treatments were a marbling score of 538, a USDA yield grade of 2.9 , with $1.51 \mathrm{~cm}$ of 12th-rib fat, and an 86.4- $\mathrm{cm}^{2}$ longissimus muscle area. Based on chi-squared analysis, no differences $(P$ $>0.50$ ) were detected in carcasses grading USDA Choice across treatments, averaging $69 \%$.

Fecal starch values were greater $(P<0.10)$ in steers fed WC + WCGF compared with all other treatments. Steers fed DRC had greater $(P<0.10)$ fecal starch values than steers fed SFC, SFC + WCGF, FGC + WCGF, or HMC + WCGF. Fecal starch values were similar among steers fed DRC, DRC + WCGF, and SFC + DRC. Steers fed DRC + WCGF and SFC + DRC had greater $(P<0.10)$ fecal starch values than steers fed SFC, SFC + WCGF, or HMC + WCGF. Fecal starch values were similar among steers fed SFC, SFC + WCGF, FGC + WCGF and HMC + WCGF.

\section{Trial 2}

Steers fed DRC + WCGF, FRC + WCGF, and HMC + WCGF consumed similar amounts of feed and averaged $11 \mathrm{~kg} / \mathrm{d}$ (Table 6). Steers fed DRC + WCGF or FRC + WCGF consumed 10,9 , or $4 \%$ more $(P<0.10)$ DM, respectively, than steers fed DRC, SFC, or SFC + WCGF. On average, steers fed SFC + WCGF or HMC + WCGF consumed 7\% more $(P<0.10)$ DM than steers fed DRC or SFC. Steers fed DRC or SFC consumed similar quantities of DM.
Daily gains were increased $(P<0.10) 8 \%$ in steers fed SFC + WCGF compared with the average of all other treatments (Table 6). Daily gains among steers fed DRC + WCGF, SFC, FRC + WCGF, and HMC + WCGF were similar. Daily gains were decreased $(P<0.10) 9.5 \%$ in steers fed DRC compared with the average of all other treatments.

Feed efficiency was greater $(P<0.10)$ in steers fed $\mathrm{SFC}$ or SFC + WCGF compared with each of the other treatments (Table 6). The improvement in feed efficiency in steers fed SFC or SFC + WCGF was approximately $10 \%$ compared with the average of the other treatments. Steers fed DRC, DRC + WCGF, FRC + WCGF, and HMC + WCGF exhibited similar feed efficiency.

Dietary $\mathrm{NE}_{\mathrm{g}}$ was $9 \%$ greater $(P<0.10)$ in steers fed SFC or SFC + WCGF compared with all other treatments (Table 6). Dietary $\mathrm{NE}_{\mathrm{g}}$ in steers fed DRC or HMC + WCGF was similar to that of steers fed DRC + WCGF and greater $(P<0.10)$ than that of steers fed FRC + WCGF. Steers fed DRC + WCGF or FRC + WCGF had similar dietary $\mathrm{NE}_{\mathrm{g}}$.

Hot carcass weights in steers fed SFC + WCGF were similar to those of steers fed HMC + WCGF and were approximately $12 \mathrm{~kg}$ heavier $(P<0.10)$ than the average of steers fed DRC, DRC + WCGF, SFC, and FRC + WCGF. Hot carcass weights among steers fed DRC + WCGF, SFC, FRC + WCGF, and HMC + WCGF were similar. Hot carcass weights of steers fed DRC were approximately $16 \mathrm{~kg}$ lighter $(P<0.10)$ compared with hot carcass weights of all other treatments. Steers fed SFC + WCGF had higher $(P<0.10)$ yield grades than steers fed DRC, SFC, or FRC + WCGF. Steers fed DRC + WCGF, SFC, FRC + WCGF, and HMC + WCGF had similar yield grades. Steers fed DRC had lower $(P<$ 
$0.10)$ yield grades than all other treatments. Steers fed SFC + WCGF had greater $(P<0.10) 12$ th-rib fat thickness compared with all other treatments except HMC + WCGF. Steers fed DRC + WCGF, SFC, FRC + WCGF, and HMC + WCGF had similar fat thickness. Steers fed DRC had lower $(P<0.10) 12$ th-rib fat thickness compared with all other treatments except DRC + WCGF. Marbling scores and longissimus muscle area were not statistically different among treatments. The averages across treatments were 505 and $90.8 \mathrm{~cm}^{2}$ for marbling score and longissimus muscle area, respectively. Based on chi-squared analysis, no differences were observed across treatments $(P>0.74)$ with an average of $56.9 \%$ grading USDA Choice or better.

\section{Discussion}

The geometric mean diameter of WC fed in Trial 1 is comparable to that of WC fed by Secrist et al. (1996a) and Turgeon et al. (1983), who reported geometric mean diameters for WC of 5,700 and 5,977 $\mu \mathrm{m}$, respectively. The geometric mean diameter of FGC fed in Trial 1 was similar to Turgeon et al. (1983), who reported a geometric mean diameter for FGC of $734 \mu \mathrm{m}$. The geometric mean diameter of both FRC (Trial 2) and HMC (Trials 1 and 2) fed to steers was greater than that fed by Secrist et al. (1996a,b), who reported values of 1,550 $\mu \mathrm{m}$ and $2,120 \mu \mathrm{m}$ for FRC and coarsely rolled HMC, respectively. However, the FRC and HMC fed in the experiments of Secrist et al. (1996a,b) were processed through a double-roller mill, whereas the corn in Trials 1 and 2 was processed through a single-roller mill.

Theurer (1999) and Owens et al. (1997) reported that cattle fed SFC finishing diets could be expected to consume 8 and $11.6 \%$ less feed, respectively, than cattle fed DRC finishing diets. In contrast, feeding SFC resulted in similar DMI compared with feeding DRC in both Trials 1 and 2. In fact, DMI was numerically increased by feeding SFC compared with DRC in Trial 2. In both Trials 1 and 2, steers fed SFC gained significantly faster than steers fed DRC. Theurer (1999) reported that cattle fed SFC finishing diets could be expected to have numerically greater $\mathrm{ADG}(2 \%)$ than cattle fed DRC finishing diets. In contrast, Owens et al. (1997) suggested that feeding SFC resulted in a $1.4 \%$ decrease in ADG. Both Theurer (1999) and Owens et al. (1997) reported that feeding SFC-based finishing diets improved feed conversion, which is in agreement with the results of both Trials 1 and 2 .

Addition of WCGF to diets containing DRC or SFC increased DMI in both Trials 1 and 2 compared with diets containing DRC or SFC without WCGF. Likewise, addition of WCGF to diets containing DRC or SFC increased ADG when compared with feeding DRC or SFC alone. Increased DMI and improved ADG are consistent with previously observed performance responses when feeding WCGF (Stock et al., 2000).

In Trial 1, feed efficiency was $3.2 \%$ poorer for steers fed DRC + WCGF than for steers fed DRC without
WCGF, whereas in Trial 2 feed efficiency was similar in steers fed DRC with or without WCGF. Feed efficiency among steers fed SFC with or without WCGF was similar in both Trials 1 and 2. In contrast, Stock et al. (2000) summarized five finishing trials and suggested that finishing diets that contained an average of $34.8 \%$ WCGF resulted in a $5.1 \%$ improvement in feed efficiency. However, in support of the decreased feed efficiency response observed in this study, Scott et al. (2001) observed a 4.8\% improvement in feed efficiency with DRC control diet vs. a DRC diet containing 35\% WCGF.

A portion of the improvement in feed efficiency when feeding WCGF in DRC finishing diets has been attributed to a reduction in subacute acidosis (Krehbiel et al., 1995). Our hypothesis was that when subacute acidosis is controlled, increased processing of corn grain would increase starch availability and feed efficiency. However, if acidosis occurs, the improvement in feed efficiency response to increased processing of corn grain would not be expected to be as great. Thus, corn-based finishing diets that contain WCGF might allow corn grain to be more extensively processed without increasing the risk of acidosis.

In finishing diets containing WCGF, the data from these trials indicate that, in general, efficiency was improved as the degree of processing was increased. Processing methods such as steam-flaking, high-moisture ensiling, and fine-grinding improved feed efficiency compared with either minimal processing methods (i.e., rolling) or no processing. Feeding SFC has been shown to improve feed efficiency compared with feeding DRC (Zinn, 1987; Barajas and Zinn, 1998; Zinn et al., 1998) or WC (Lee et al., 1982). Feeding HMC has generally resulted in feed efficiency similar to that observed when feeding DRC (Owens, et al., 1997; Stock et al., 1987b) or WC (Stock et al., 1987a). In contrast, feed efficiency was improved in steers fed HMC + WCGF in Trial 1 when compared with steers fed DRC + WCGF or WC + WCGF.

Although rate of gain was not affected, feeding WC + WCGF increased DMI and decreased feed efficiency compared with each of the other processing methods in Trial 1. In contrast, Owens et al. (1997) indicated that feeding WC resulted in DMI and feed efficiency similar to that of steers fed SFC and reduced DMI and improved feed efficiency compared with steers fed DRC or HMC.

In Trial 2, steers fed FRC + WCGF had feed efficiency similar to that observed in steers fed DRC + WCGF, which is consistent with the data of Secrist et al. (1996a), who reported similar feed conversion between steers fed coarsely or finely rolled corn having a geometric mean diameter of 3,100 and $1,550 \mu \mathrm{m}$, respectively. In Trial 1, steers fed FGC + WCGF were more efficient than steers fed DRC + WCGF or WC + WCGF, which is in contrast to Turgeon et al. (1983), who reported similar feed efficiency among steers fed DRC, FGC, or WC. Therefore, feeding FGC may be possible in diets containing WCGF due to more uniform diets in the 
Table 7. Net energy for gain $\left(\mathrm{NE}_{\mathrm{g}}\right)$ calculations for $\mathrm{DRC}, \mathrm{SFC}$, and WCGF in Trials 1 and 2

\begin{tabular}{llllc}
\hline \hline & \multicolumn{3}{c}{ Ingredient $^{\mathrm{a}}$} \\
\cline { 2 - 5 } Item & $\mathrm{DRC}$ & $\mathrm{WCGF}^{\mathrm{b}}$ & $\mathrm{SFC}$ & WCGF $^{\mathrm{c}}$ \\
\hline Trial 1 & & & \\
$\mathrm{NE}_{\mathrm{g}}, \mathrm{Mcal} / \mathrm{kg}^{\mathrm{d}}$ & 1.66 & 1.38 & 1.74 & 1.61 \\
$\%$ Difference & & 6.4 & 7.2 & 23.6 \\
Trial 2 & & & & 1.65 \\
$\mathrm{NE}_{\mathrm{g}}, \mathrm{Mcal}^{\mathrm{e}} \mathrm{kg}^{\mathrm{d}}$ & 1.55 & 1.33 & 1.66 & 2.3 \\
\% Difference & & 2.5 & 2.3 & 27.0 \\
\hline
\end{tabular}

${ }^{\text {aDRC }}=$ dry-rolled corn; SFC = steam-flaked corn; WCGF = wet corn gluten feed .

${ }^{\mathrm{b}}$ Fed in DRC-based finishing diet.

${ }^{\mathrm{c}} \mathrm{Fed}$ in SFC-based finishing diet.

${ }^{\mathrm{d}} \mathrm{NE}_{\mathrm{g}}$ of ingredient calculated from animal performance by difference.

ePercent difference from NRC (1996) tabular value for DRC, SFC, or SCGF, respectively.

bunk (i.e., preventing small particles from accumulating) and a reduction of subacute acidosis associated with faster rates of starch digestion with FGC.

During Trials 1 and 2, we observed more whole corn kernels in the feces of steers fed WC and more whole and large broken kernels in the feces of steers fed DRC than those fed SFC, HMC, or finely processed corn. Fecal starch analysis indicated that feeding SFC decreased fecal starch compared with feeding WC or DRC. These results are consistent with previous research results in which fecal starch values were decreased with SFC vs. DRC (Barajas and Zinn, 1998) and SFC vs. WC (Lee, et al., 1982). Also, fecal starch tended $(P<0.11)$ to be reduced in steers fed FGC + WCGF and was reduced $(P<0.08)$ in steers fed HMC + WCGF compared with DRC + WCGF The differences in fecal starch when feeding DRC + WCGF compared with FGC + WCGF and HMC + WCGF indicate that fecal starch could be reduced by finely grinding or high-moisture ensiling corn when compared with dry-rolling. Because fine grinding and high-moisture ensiling increase the rate of starch digestion (Huntington, 1997), inclusion of WCGF in these diets may minimize challenges associated with more rapid rates of starch digestion. Passage rate has been shown to increase with the addition of WCGF to corn-based finishing diets (Montgomery et al., 2001). Thus, when corn is less extensively processed, feeding WCGF may increase rate of passage such that starch digestion of the large grain particles is reduced. A reduction in starch digestion would presumably decrease feed efficiency despite similar ADG. Based on animal performance, the $\mathrm{NE}_{\mathrm{g}}$ calculated for WCGF (Table 7) was 16.7 and $24.1 \%$ greater in steers fed SFCbased finishing diets than in steers fed DRC-based finishing diets in Trials 1 and 2, respectively. The greater $\mathrm{NE}_{\mathrm{g}}$ estimates for WCGF in SFC- vs. DRC-based finishing diets supports the hypothesis that more extensively processing corn can serve to further improve feed efficiency in corn-based finishing diets that contain WCGF.

\section{Implications}

These results indicate that feeding steam-flaked corn results in improved feed efficiency with or without the inclusion of wet corn gluten feed compared with feeding dry-rolled corn. These data also indicate that grain processing methods that are more intensive than dry-rolling can be used to further improve feed efficiency and dietary net energy available for gain in finishing diets containing wet corn gluten feed.

\section{Literature Cited}

ASAE. 1969. ASAE Standard S319. Method of determining and expressing fineness of feed materials by sieving. Page 346 in Agricultural Engineers Handbook. Amer. Soc. Agric. Eng.

Barajas, R., and R. A. Zinn. 1998. The feeding value of dry-rolled and steam-flaked corn in finishing diets for feedlot cattle: Influence of protein supplementation. J. Anim. Sci. 76:1744-1752.

Huntington, G. B. 1997. Starch utilization by ruminants: From basics to the bunk. J. Anim. Sci. 75:852-867.

Krehbiel, C. R., R. A. Stock, D. W. Herold, D. H. Shain, G. A. Ham, and J. A. Carulla. 1995. Feeding wet corn gluten feed to reduce subacute acidosis in cattle. J. Anim. Sci. 73:2931-2939.

Lee, R. W., M. L. Galyean, and G. P. Lofgren. 1982. Effects of mixing whole shelled and steam flaked corn in finishing diets on feedlot performance and site and extent of digestion in beef steers. J. Anim. Sci. 55:475-483.

Montgomery, S. P., J. S. Drouillard, E. C. Titgemeyer, J. J. Sindt, T. B. Farran, N. J. Pike, C. M. Coetzer, A. M. Trater, and J. J. Higgins. 2001. Effects of wet corn gluten feed and intake level on diet digestibility and rumen passage rate in steers. Kansas Agric. Exp. Stn. Rep. of Prog. 873:80-82

Murphy, T. A., F. L. Fluharty, and S. C. Loerch. 1994. The influence of intake level and corn processing method on digestibility and ruminal metabolism in steers fed all-concentrate diets. J. Anim. Sci. 72:1608-1615.

NRC. 1996. Nutrient Requirements of Beef Cattle. 7th ed. Natl. Acad. Press, Washington, DC.

Owens, F. N., D. S. Secrist, W. J. Hill, and D. R. Gill. 1997. The effect of grain source and grain processing on performance of feedlot cattle: A review. J. Anim. Sci. 75:868-879.

Scott, T., C. Milton, and T. Klopfenstein. 2001. Programmed gain finishing systems in yearling steers fed dry-rolled corn or wet corn gluten feed finishing diets. Nebraska Beef Cattle Rep. MP 76A:49-51. 
Secrist, D. S., W. J. Hill, F. N. Owens, D. R. Gill, and S. D. Welty. 1996a. Rolled or whole corn for feedlot steers being limit or ad libitum fed. OK. Agr. Exp. Stn. Res. Rep. P-951:173-180.

Secrist, D. S., W. J. Hill, F. N. Owens, C. A. Strasia, D. R. Gill, and J. B. Duggan. 1996b. Effects of particle size distribution of high moisture corn on performance and carcass characteristics of feedlot steers. OK Agr. Exp. Stn. Res. Rep. P-951:144-152.

Stock, R. A., D. R. Brink, R. T. Brandt, J. K. Merrill, and K. K. Smith. 1987a. Feeding combinations of high moisture corn and dry corn to finishing cattle. J. Anim. Sci. 65:282-289.

Stock, R. A., D. R. Brink, R. A. Britton, F. K. Goedeken, M. H. Sindt, K. K. Kreikmeier, M. L. Bauer, and K. K. Smith. 1987b. Feeding combinations of high moisture corn and dry-rolled grain sorghum to finishing steers. J. Anim. Sci. 65:290-302.

Stock, R. A., J. M. Lewis, T. J. Klopfenstein, and C. T. Milton. 2000. Review of new information on the use of wet and dry milling feed by-products in feedlot diets. Proc. Am. Soc. Anim. Sci., 1999.
Available at: http://www.asas.org/jas/symposia/proceedings/ 0924.pdf. Accessed 18 July 2000.

Theurer, C. B., R. Wanderley, and J. T. Huber. 1999. Steam-flaking of grains improves nutritional value for growing-finishing beef cattle and lactating dairy cows. Pages 74-83 in Symp. Proc.: Intermountain Nutr. Conf. on Nutr. and Nutritional Management of Dairy and Beef Cattle. Publ. 160. Utah Agric. Exp. Stn., Logan, UT.

Turgeon, O. A., Jr., D. R. Brink, and R. A. Britton. 1983. Corn particle size mixtures, roughage level and starch utilization in finishing steer diets. J. Anim. Sci. 57:739-749.

Zinn, R. A. 1987. Influence of lasolocid and monensin plus tylosin on comparative feeding value of steam-flaked versus dry-rolled corn in diets for feedlot cattle. J. Anim. Sci. 65:256-266.

Zinn, R. A., E. G. Alvarez, M. F. Montano, A. Plascencia, and J. E. Ramirez. 1998. Influence of tempering on the feeding value of rolled corn in finishing diets for feedlot cattle. J. Anim. Sci. 76:2239-2246. 